\title{
Smart State: Queensland in the Knowledge Economy
}

\author{
Gillian Sullivan Mort and Amanda Roan ${ }^{1}$
}

\begin{abstract}
This paper aims at providing some understanding of emerging elements of the knowledge economy and the policy frameworks that might be developed to foster regional entities that will prosper by meeting the challenges of engagement in the global knowledge economy. Through a review of extant and emerging literatures a novel conceptual framework is developed to assist in policy evaluation and development. This framework is then applied to Queensland's Smart State suite of policies. The paper concludes that Queensland has in place many elements of the policy framework required to foster a knowledge economy. It is argued however that several tensions within the policy framework are evident, and as this is an emergent area of policy development, further in-depth evaluation of both the policy settings and the effectiveness of policy is warranted.
\end{abstract}

\section{Introduction}

A major task of the Queensland Government has been to foster Queensland's economic development through engagement in the global knowledge economy. The purpose of this paper is threefold. First it provides a reflection on the knowledge economy and its relevance to economic development in Queensland. The second purpose is to propose a framework for assessing economic development strategies in a knowledge economy and, third, the paper offers a preliminary analysis of the 'Queensland: Smart State' initiatives by examining Smart State policy statements. It is beyond the scope of this paper to attempt a detailed evaluation of the effectiveness of the policies being enacted in Queensland. This paper is positioned as a necessary preface to such a fuller and more complete evaluation and analysis. 


\section{The Knowledge Economy}

The knowledge economy, though lacking a universally accepted definition, is the term generally used to describe the emergence of economies based on the production, distribution and use of knowledge and information (Clarke 2001). It is argued that '[T] the success of enterprises, and of national economies as a whole, is ever more reliant on their effectiveness in gathering and utilizing knowledge' (OECD 1996: 14), with knowledge as a value-added input to the economic system. As early as the 1960s and 1970s, (Bell 1974) clearly identified that post-industrial society would be a knowledge society. A knowledge society was one with the sources of innovation being derived from theoretical knowledge based on research and development and the majority of GNP being derived from the knowledge field. Despite the difference in the unit of analysis, that is at the level of economy or more broadly at the level of a society, there is broad agreement on the importance of knowledge (see for example Neef 1998). Despite the wide discussion and influence of Bell's early work in the area, the seemingly abrupt arrival of the knowledge economy/society has provided challenges to government, industries, firms, community and individuals. Individuals, organizations and institutions are challenged to move from understandings of economies based on comparative advantage of land, labour and capital, and firm level strategies based on competitive advantage. They are challenged to move to an understanding of an economic system of endogenous growth based on innovation and the creation of knowledge and ideas within the system (Grossman and Helpman 1995; Romer 1994), and at the firm level the creation of fundamentally new and different value by leveraging intellectual or knowledge assets (Kim and Mauborgne 1999; McGaughey 2002). Knowledge has been identified as the key commodity of the future (Queensland Government 2001). Knowledge and ideas are posited by some as infinite economic goods that generate increasing returns through their systematic use (Kim and Mauborgne 1999), while others (Boisot 1998; McGaughey 2002) also emphasize the importance of scarcity in the value of intellectual assets.

Considering Queensland's future in the knowledge economy it is timely to reflect that Australia's and Queensland's economic development had long been premised on the export of agricultural and mineral products under favourable terms of trade, along with the development of a protected manufacturing and later service sector. Beginning in the 1980s governments of both political persuasions have, at the national level, embraced a generally much smaller role for government, with market forces deemed to be sufficient to deliver the best outcomes for the national economy.

In his influential book of the early 1990s, Porter (1990) identified the role of government as influencing the four determinants of national competitive advantage: factor conditions, demand conditions, firm strategy, structure and rivalry and related and supporting industries interrelated in the systemic 'diamond'. Porter (1990) assigned a central role in national competitive advantage to innovation in existing industries and the capacity to compete successfully in new industries, arguing that government policy at local, state or national level should stimulate such dynamism 
and upgrading across industries. However, he also argued that the role of government is inherently partial and indirect and works by influencing context and institutional structure as well as the inputs that firms can draw upon. The debate is now moving away from conceptions of national competitive advantage in the Porter (1990) framework, towards global interlinked economies, firms and industries (e.g. Enright and Roberts 2001; Porter and Stern 2001) with the role of innovation of industry clusters and linkages being emphasized. As a result the role of government now also pertains to facilitating the linkages between the clusters, for example, in fostering the relationships between universities and firms and industry.

Thus it is argued (Cairney 2000) that regions seeking to compete more effectively in the world economy will need systems and structures that support knowledge creation and learning, collaboration and linkages among individuals, firms, community organizations and institutions within regions and across regions and nations. Given that the national policy context in Australia continues, despite a number of initiatives, to be rather constrained by a narrow consensus on a limited role for government and a reliance on market forces, the ability to frame policy at the state/regional level that can facilitate the emergence of the knowledge economy has become of increasing significance.

It has further been argued (Marsh 2001) that during the long period of development up to the 1980s, social and economic policy were closely entwined, with the concept of Australia as the 'working man's paradise' and egalitarian values becoming firmly embedded in the national psyche. There is still, it is argued, a general expectation that social as well as economic policy is the work of government, which is an important issue to consider when examining the knowledge economy in Australia.

\section{The Knowledge Economy and Policy Frameworks}

Policies aimed at facilitating economic development, and the restructuring of industrial sectors, come under the general area of industry policy. Indeed, since the 1980s an impressive number of volumes and articles have been written attempting to isolate factors that contribute to the industrial performance of economic regions (see for example Bell 1997; Capling and Galligan 1992; Cohen and Zysman 1987; Porter 1990). At a policy level the debate surrounds the role of the state and public policy in economic activity, the extent to which public policy should intervene in production, the areas appropriate for intervention and the appropriate policy instruments.

Traditionally, the differing approaches to industry policy and the restructuring of the economy have been categorized into strategic/managed or free market approaches (Hart and Richardson 1993). The free market approach rejects the state's ability to manage industry policy with its role confined to setting an appropriate macro-economic climate. In the free market approach, the discipline of market mechanisms is permitted to decide the industrial production to be pursued. In contrast, the strategic/managed industry policy approach covers a diverse range 
of strategies and approaches. It can include the state directing and planning industry development, the provision of subsidies and the now discredited system of protective tariffs (Bell 1993). Also contentious in this approach is deciding the appropriate industries to be fostered to meet a country's economic and social needs (see Bell 1993 and Stewart 1990). During the late 1980s and early 1990s numerous commentators argued that for Australia to maintain and increase the quality of employment and its standard of living a viable manufacturing industry based on elaborately transformed manufacturing was necessary (Higgins and Ewer 1987; Pappas et al 1990), while in the early to mid 1990s growing service industries such as tourism, hospitality and education services were seen as having the potential to meet Australia's needs in these areas (Austrade/LEK 1994; Industry Commission 1995).

It appears that this optimism has now been directed at knowledge industries and the general concept of a knowledge economy, however it is suggested that the appropriate policy framework is more complex than the market versus intervention dichotomy previously guiding policy debate. Preliminary evaluation of the literature reveals that a hybrid policy process of climate setting, infrastructure development and the encouragement of innovation, entrepreneurship and research and development is emerging. However, in Australia the policy framework is complicated by the existence of the federal system. State governments such as Queensland work within the economic and policy framework of the Australian government, are subject to federal revenue-raising and revenue-sharing arrangements (see Groenewgen 1994), and compete with other states in attempting to attract private investment. Therefore, the policy instruments available differ with state and federal responsibilities and the political orientation of particular governments.

Although there is a growing literature on the new economy and the knowledge economy, conceptual frameworks that can assist with the analysis and development of economic policy in this area are underdeveloped. Cairney (2000) offers three views of the drivers of the knowledge-based economy emerging from the current literature. These are first the view, most evident in the OECD publications, which sees it as very much bound up with the high skills/high performance/high value added [firm] competing in the globalised economy scenario. Second, the view of the scientific and technical community that tends to focus more narrowly on knowledge intensive industries where knowledge itself is a core competence. Third, Cairney (2000) broadened the definition to define the knowledge economy to be an economy increasingly dependent for its growth on the input of knowledge as a value-added input to the economic system as a whole. We will now elaborate on these aspects of the knowledge economy before using them to provide a basis of a framework for analyzing Queensland's Smart State policies.

\section{High skills/high performance}

In what has become a seminal article Finegold and Soskice (1988) put forward the idea of 'a low skills/low quality equilibrium' that was leading to a less than optimum performance by British industry. The link between the level of education 
of the workforce, the performance of the economy, and its transition to new levels has come to be accepted by most as axiomatic. Over the last decade debates about education and vocational education have acquired a distinctive prominence and urgency. Indeed Crouch, Finegold and Sako (1999: 1) describe what is almost a Utopian vision of the knowledge society as follows:

...almost without unskilled, low-productivity people, in which all mindless physically damaging jobs are carried out by robots; income differentials are compressed through the market-compatible device of overcoming the scarcity of high skill...Such a Utopia would be compatible with many of the aspirations of both the political left seeking a reduction of material inequalities and right seeking to achieve any social goals through market-compatible means. (Crouch, Finegold and Sako 1999: 1).

However, others (Cairney 2000) maintain that the knowledge economy is not so much concerned with higher skills as the needs of business enterprises for a broader range of aptitudes, abilities and skills that can be applied to new ways of thinking and managing. If Cairney's view is correct then, while higher skill levels and education are important, policy will also need to be developed beyond general and vocational education, workplace skills and life-long learning, to learning in the broader context of the business and social networks necessary in the knowledge economy.

\section{Knowledge intensive industries}

The term 'information society' has been used to describe the transformations in capitalist economies and societies from the 1970s resulting from new computer, communications, and media technologies. For Dow and Parker (2001) the knowledge economy highlights the way information is used in business processes and the design of new products. The design of new products is not confined to Information and Communication Technology (ICT). As Sheehan and Tikhomirova (1998) note, knowledge intensive manufacturing industries, such as electronics and Pharmaceuticals, and service industries, such as database and information services, are also part of the information age. For many (e.g. Jones 1990) the knowledge intensive industries also include the 'sunrise industries' such as biotechnology, nano-technology, robotics etc, indeed any new high tech application around which an industry can or might develop. In a study of sectoral change in Japan, Satoh, Nakayama and Wakuta (2002: 1) point out that industrial leadership has moved from 'Iron is the Nation state' and 'those who control the Oil rule the world' philosophy toward the promise of bio-business. Satoh, Nakayama and Wakuta (2002) note that there are more than 1,300 bio and genome-related companies in the United States and 1000 companies in the European Union and that the Japanese government hopes to build 130 companies in this area to more than 1,000 by the year 2010. Singapore has also recently moved in this direction and a recent shift in Research and Development (R\&D) strategies has also been apparent in Australia 
(see Queensland Government 2001: 13-14) heralding a wide acceptance of the role of knowledge intensive industries as an integral part of developing a knowledge economy.

Current economic development is not just about movement in Australia's economic structure. Networks, clusters and complexes form part of this new industrial development. Building on Porter's (1990) work outlined above, Marceau and Manley (2001: 84) state that 'firms are no longer viewed atomistic organisations but a part of numerous systems that link their activities with their survival and growth dependent on the sharing of information and other activities related to successful innovation.' Therefore, success in the knowledge economy will require the facilitation of inter-organisational relationships and networks often built within geographic areas or clusters (Porter and Stern 2002). Clearly, such a requirement will have appeal to those endeavouring to foster regional development.

\section{Inputs of knowledge}

Inputs of knowledge cannot be isolated from the two categories mentioned above, however, the generation of new ideas is commonly understood to have become increasingly important, along with the capacity to test those high-risk and uncertain ideas in a commercial setting (Dow and Parker 2001). This generation and commercial application of new ideas is generally conceptualized under the term 'innovation'. Of course, innovation is not new. The huge technological leaps made in the $20^{\text {th }}$ century, and on which the knowledge economy is premised, would not have been possible without the existence of innovative processes and people. What is new is a search to capture, formulate and codify these abilities, to understand the processes involved, as well as the tangible products of innovation, and to infuse all aspects of the economy and wider society with the abilities to harness knowledge as an input to economic development (see Neef 1998; Roberts 2002). Within firm knowledge development is also important yet relatively little understood with an emerging focus on knowledge management and learning organizations. For example Roth et al (1994) argue that organisations need to understand how core knowledge drives their business and develop the skills to acquire, organise, codify and deploy this knowledge.

The principle elements of Cairney's (2000) framework are high skills/high performance, knowledge industries and inputs of knowledge. Though seemingly comprehensive, it is argued that these are insufficient to examine the policy frameworks being developed for the knowledge economy because they neglect to position the knowledge economy as an element of knowledge society. Bell (1974), in founding the discussion of the changes in post-industrial systems, clearly identified that the unit of analysis would be that of society, the knowledge society, rather than simply the economy. This is consistent with Marsh's (2001) arguments that economic and social policy have traditionally developed in tandem in Australia. Thus by identifying the unit of analysis as society rather than simply economy, the role of identity and image, culture and community also become an important part of a policy analysis framework. 


\section{Identity and image}

The role of identity, or as it is most often termed, national image, and the subsequent impact of the image through the 'country of origin effect' (Peterson and Jolibert 1995) has a significant influence on the competitive advantage of nations which is supported by an extensive literature in international marketing and international business (e.g. Jaffe and Nebenzahl 2001; Papadopoulos and Heslop 1993; Peterson and Jolibert 1995; Schooler 1965). In essence, the image of a nation with a strong positive image consistent with the product category under consideration will exert a positive halo over attributes and brand attitudes, leading to increased likelihood of purchase; over time and with experience of the product itself the image will become modified, and the country image becomes a summary of all the past experiences with products (Jaffe and Nebenzahl 2001). During the long economic ascendancy of Japan in the latter part of the $20^{\text {th }}$ century what was most often remarked upon was the changed image for quality, reliability and technical innovation of its products that contributed to the wide international acceptance of, and indeed preference for, Japanese products and greatly contributed to the nation's success (Darling and Wood 1990; Nagashima 1970; Nagashima 1977). The extension of country image beyond products and towards service image, has also been researched for Australia in the APEC region (Sullivan Mort 1999). A reciprocal influence of brands on the country image itself (Anholt 2002), where for example what is known of Switzerland may be known through the brands Swatch watches or Swiss Army knives, has also been highlighted.

Recently (Anholt 2002; Kotler, Haider and Rein 1993; Kotler, Jatusripitak and Maesincee 1997; Kotler and Gertner 2002) there has been a fresh interest in nation image, beyond its more straightforward effect and influence on products, services and brands. The image of and marketing of a place, such as a nation or a region or a city has been considered influential in attracting tourism, business, expanding exports and stimulating foreign investment (Kotler 1993). The branding of Silicon Valley in the US and the re-imaging of Ireland as the 'Celtic Tiger' are well known examples of the broader advantages of a well known place image in mediating the relationship with communities of interest, such as investors, skilled migrants and hi-tech businesses. The ability to consciously re-image and re-position places and indeed countries is becoming much better understood (e.g. Morgan, Pritchard and Piggott 2002; Gilmore 2002) involving an analysis of macro-trends, target groups, competitors and core competencies supported by consumer research and based on multi-agency strategies. What is also receiving attention is the 'internal' branding aspects of branding a place or a nation. In marketing jargon, the question of how to get the population behind the brand and make them 'live the brand' has also been commented upon as an important issue for further research (Anholt 2002). 'Living the brand' (Ind 2001) means accepting and enacting the brand values and has an allied meaning in the corporate culture literature as an aid to organizational transformation and change management. For nation states seeking transition to a relevant knowledge economy image, this would involve identification of core, and newly emerging, competencies, and the development of a nation self image constructed around these. 


\section{Culture and community}

Along with predictions of growth of the 'new' knowledge-based economy predictions of a divided society divided between the information rich versus information poor emerged. In the late 1980s (Castells 1989), a sociologist and urban planner left little doubt about the centrality of technical skills and knowledge to what he referred to as the developing information economy. Castells (1989: 15) describes the key elements in 'fostering or stalling the new information based productive forces' as 'the productive organisations, social institutions and the overall structure of society, including its ideology'; that is forces that extend far beyond the unit of the firm. Sassen (1991) analysed production employment in what she termed 'global cities' such as London, Tokyo and New York, which showed a deterioration of an active manufacturing sector and rapid growth of a producer service sector, notably financial and management services. Her analysis offers a picture of a divided society. She identified an increasing division of labour within even technologically advanced countries, with knowledge-rich skilled workers being supported within their industry by lower skilled workers, and the lifestyle of the knowledge-rich workers supported by lower-paid service workers often working through temporary or casual arrangements (Sassen 1991: 217-219). The challenge for a region is not only to build a skilled workforce and an innovative culture but also to address questions of participation and opportunity within the knowledge economy. Thus we propose a novel framework of high skills/high performance, knowledge intensive industries, inputs of knowledge, identity and image, culture and community on which to develop and evaluate policy for a knowledge economy.

\section{The Queensland Approach}

Having established a policy evaluation framework, this section now provides an analysis of the policy initiatives undertaken in Queensland. To aid understanding of aspects of the Smart State a brief examination of the policy foundations will be followed by an analysis summarized under the framework outlined above. It should be stressed that this is a preliminary analysis based on policy statements only and does not present an evaluation of outcomes. Table 1, at the end of this section, provides a brief, guiding summary of the policy instrument and their use in the Queensland context.

\section{Policy Foundations}

Smart State Jobs for the Future Policy Statement (Queensland Treasury 2000: 3) states that the heart of the Smart State is to create jobs for the future for Queensland. This statement is used as a central point of the analysis as the policies are strongly branded 'Smart' and set the framework of policies that were intended to establish Queensland as the 'Smart State'. The 2002 budget policy statement was entitled 'Queensland - Growing the Smart State (Queensland Treasury 2002), continuing 
the policy direction. The policy initiatives in the 2000 (Queensland Treasury 2000) statement are summarized under the following headings:

1. Education for life

2. Building job opportunities

3. Foundations for growth

4. Industry development

5. Culture and Community

6 . Working with the World

7. Innovation

Closer examination of these policy areas reveals that this framework allows the Queensland government to place most of the business of government under the 'smart' brand. In the 2000 budget papers expenditure on health, education, police and the arts are all gathered into the 'Smart State' framework. For example, budget allocations under 'foundations for growth' included for traditional economic development infrastructure such as roads and power stations as well as health and housing. Further the Smart State branding was extended to family support policy presented as Queensland the Smart State - Putting Families First when government funding for children at risk was increased after the Forde Inquiry into the abuse of children in Queensland institutions (see Queensland Government 2000).

This broad sweep of policy has led to Smart State initiatives and responsibilities being spread across a number of departments. The most notable are the Premiers Department, Queensland Treasury, State Development and The Department of Innovation and the Information Economy.

It is beyond the scope of this paper to fully discuss the details of the Smart State initiative. However, the Department of Innovation and Information Economy outlines its policies under the following headings:

- Information Economy

- Science and Research

- Innovation

In contrast to the 2000 Smart State Budget statement, this policy frame focuses squarely on ICT and Bio discovery through the mediums of research and development R\&D and innovation. (For access to the multiple policy statements, documents and proposals see <www.diiesrq.qld.gov.au/policy>).

Even in this brief overview of the policy foundations, the tension between focused industry-based policy, as in the Department of Innovation and Information Economy documents, and the broader concept of community involvement in the knowledge economy, as exemplified by the broad sweep of the budget papers, is apparent.

\section{High skill/high performance}

The 2000 and 2002 Smart State budgets statement reveals a relatively conventional approach to skills and training. (In $200226 \%$ of the budget allocation was directed at education expenditure [Queensland Treasury 2002:4]). Investment in education infrastructure, more teachers and IT driven investment in Technical and Further Education Institutes TAFE was undertaken. The quest for a higher skill level in the 
broader population is apparent in curriculum development focused on criticalthinking, problem solving and life-long learning skills.

However, the political reality of election promises for a government elected 1998 and re-elected 2001 on a platform of reducing unemployment determines that skills and training are combined with promoting apprenticeships and traineeships and community jobs plans as evident in the 2000 budget papers (Queensland Government 2000: 8).

\section{Knowledge intensive industries}

Perusal of strategy statements and policy documents reveals a clear emphasis on the emerging industries identified in the international literature, particularly ICT and Bio-technology, with an emphasis on ICT then referred to as Information Technology and Telecommunications (IT \& T) sector in the earlier document (Queensland Government 2000). However, in later documents focus on investment in bio discovery is considerable. Australia is described as 'one of only twelve mega [their emphasis] bio-diverse countries in the world with Queensland possessing a significant proportion of this resource' (Queensland Government 2002: 4). The Smart State Strategy funding allocation for the development of Queensland's bioindustries is listed at $\$ 270 \mathrm{M}$ and the list of $\mathrm{R} \& \mathrm{D}$ facilities provided includes centres based at most of Queensland's universities, the Commonwealth Scientific Industrial Research Organisation CSIRO and a number of state government departments (Queensland Government, 2002).

The attraction of the 'bio' prefaced industries is obvious. As stated above, these are industries that have demonstrated themselves to be increasingly profitable (see Satoh, Nakayama and Wakuta 2002) and Queensland possesses the raw material (Queensland Government 2002). However 'bio' can incorporate food production, the natural and marine environment, as well as the highly technical and professional areas of drug design and Pharmaceuticals. Given the breadth of affiliation, the bioindustries possess the potential to satisfy many political stakeholders.

It is useful to contrast this enthusiasm for the 'bio' world with the figures on research and experimental development contained in the Queensland Government's (2002a) Queensland R\&D Strategy Issues Paper. This reveals that in 1998-99 state government investment on R\&D was concentrated in Agricultural Sciences (52.4 percent) and Medical and Health Sciences (12.8 percent). It is not clear how much of this will be re-classified as 'bio'. In contrast business expenditure was concentrated in general engineering (38.3 percent), applied sciences and technologies (32.7 percent) and ICT (18.4 percent). Queensland government expenditure on ICT was listed as 1.7 percent. It is not clear whether this dichotomy of investment results in a complementary industry performance or business expenditure ultimately needs to be redirected.

On the important question of linkage between research and development, firms and industry the Queensland Innovation Council provide a discussion titled Development of Technology Incubators, Parks and Precincts in Queensland - A Review and Start-Up Guide for Proponents (Queensland Innovation Council 2001a). 
Although warning that the clear purpose and role of these kind of facilities must be established and that the achievement of the necessary 'scale' for technology parks will be difficult particularly in regional areas, their role in the development of local economies is endorsed.

\section{Inputs of Knowledge}

Within this category two documents can be used to illustrate the Queensland approach: Innovation Directions for Queensland 2001 and Development of Technology Incubators, Parks and Precincts in Queensland. The first of these documents outlines innovations directions as follows:

- A pervasive culture of innovation

- World-class integrated education and training system

- Excellence in research

- A supportive entrepreneurial environment (Queensland Innovation Council 2001: 2).

In the first and last direction we see some attempt to deal with the rather ill-defined concept knowledge inputs. A pervasive culture of innovation is defined as 'the valuing of innovation' which needs 'awareness and deeper understanding' and 'support and participation' of the entire community (Queensland Innovation Council 2001: 16). This culture includes making heroes of innovators and fostering of innovation within the public service but does not grapple with the culture of firms in Queensland. The section on the supportive entrepreneurial environment deals with questions of laws, regulations, investment and red tape. However, it is here that some mention is made of penetrating the internal working of the firm rather than just dealing with its environment in that this document recommends 'increasing the entrepreneurial and business skills that will support the establishment and sustainability of new enterprises created' (Queensland Innovation Council 2001: 19).

\section{Beyond the square - image and identity and culture and community}

The Queensland Innovation Council lists one of its 'challenges for Queensland' as being 'encouragement to think outside the square' (Queensland Innovation Council 2001: 16). Perusal of the policy documents points to two features of the Smart State policy framework that do not form part of Cairney's (2000) review of the knowledge economy literature, but are incorporated in the extensions proposed above.

First, Queensland's Smart State policy is also distinguished from the Cairney (2000) framework for building a knowledge economy by its emphasis on branding or in fact re-branding Queensland. No longer the Sunshine State, consistent with its previous competencies in agriculture, mining and tourism, Queensland has been re-imaged and re-branded as The Smart State'.

Having previously reviewed the bases for re-imaging and re-branding, a brief examination is now made of the development and use of the 'Smart State' image. In a ministerial statement on 14 December 1998 Peter Beattie, the new Premier of 
Queensland, stated that his top priority for Queensland in 1999 was 'jobs and more jobs' (Beattie 1998). He also listed other priorities as interstate business investment, building Queensland's regions and making Queensland the 'smart state', by improving the workforce skills base and raising general education levels (Beattie 1998). By May 1999, when the Premier led a high tech trade mission to the USA, he announced that he was seeking proven methods of building new age industries which would give a golden future for jobs (Beattie 1999). This was, he identified, part of his strategy for making Queensland the 'Smart State' (Beattie 1999). The 'smart state' had now become the 'Smart State' in media statements. Further, he explicitly identified encouraging a positive image of Queensland in the United States as one of his objectives. The budget of that year, the Millennium Budget, promised to focus on building the Smart State and the Smart State brand was tied to investing in industries for the future, investing in infrastructure and in training (Queensland Treasury 2000). Through 2000 and 2001 the 'Smart State' brand continued to be applied to government initiatives as diverse as family policy and child abuse prevention, computers in schools and extensions to the police community programs. In 2001, the 'Smart State' message was literally being driven home by the introduction of Smart State registration plates for vehicles with the aim of reinforcing the Smart State theme. These themes were identified as an international reputation as Australia's Smart State, especially in information technology and biotechnology, and that Queensland was innovative and energetic, with exciting employment opportunities and sound economic initiatives (Beattie 2001). 'It's about Queensland - about our strengths, our triumphs and our future,' he stated (Beattie 2001).

Thus the State Government is attempting to re-shape image and identity. The image being projected is fairly malleable but has a focus on knowledge intensive industries, innovation environment, training and skills development.

The second feature is the broader reference to community and culture that can be found within most of the policy strategy and policy statement documents examined. It has been noted that the Smart State brand was initially pervasive encompassing most areas of economic, social and political life within the state. 'Culture and community' was a heading of the 2000 Smart State budget summary (Queensland Treasury 2000: 15). A critical interpretation of such inclusiveness could be that of the political need to capture as many stakeholders and therefore votes as possible. However, as Wiltshire (2002) points out, there is international recognition that the 'knowledge economy' needs to be recast as the 'knowledge society' so that benefits from knowledge and innovation spread through the community. In this sense the Queensland initiatives are praiseworthy, yet the attempts at inclusiveness have a tendency to weaken the central identity of the brand 'Smart State'.

As noted above, a key question facing knowledge economies is the distribution of opportunities, particularly employment opportunities. 'Jobs' was a key emphasis of the 2000 budget with an emphasis on training and skills, apprenticeships and traineeships, and the building of new industries (Queensland Treasury 2000). However, it is beyond the scope of this paper to provide any evaluation of job 
creation. Again, the Queensland initiatives portray a broad understanding of the need to develop an inclusive knowledge economy/society.

\section{Table 1 Policy Intruments And Queensland Examples}

\begin{tabular}{ll} 
Policy Instrument & Examples of Queensland Policy \\
\hline High skill/high performance & $\begin{array}{l}\text { TAFE, Education Infrastructure, IT } \\
\text { investment, teacher education, } \\
\text { apprenticeships and traineeships, } \\
\text { employment programs }\end{array}$ \\
\hline
\end{tabular}

Knowledge intensive industries ICT, bio-technology, bio-diversity, health, primary industries and mining

Inputs of knowledge

Streamlining of laws, regulations and redtape

Incubators, parks and precincts

\begin{tabular}{ll} 
Identity & Comprehensive branding \\
\hline Community & $\begin{array}{l}\text { Unemployment policies, life-long learning, } \\
\text { community development }\end{array}$ \\
\hline
\end{tabular}

\section{Conclusions and Recommendations}

The purpose of this paper has been threefold. The first purpose was to define the knowledge economy as a context for later discussions. Second, we have gone some way towards conceptualising a novel framework within which regional development policies in a knowledge economy can be developed and evaluated. Finally, we have applied this conceptual framework to the policy directions emerging in Queensland.

In applying this framework to Queensland's Smart State initiatives a number of tensions are revealed. First, the 'Queensland: Smart State' policy statements are argued to reflect an emergent view of the elements of the knowledge economy's economic and social policies relevant to its development. Indeed, the architects of policy have managed to capture most of the issues identified within the framework developed here. However, it is not clear whether such a broad sweep of policies and the associated branding represent a developed and coherent approach. Evaluation and consolidation are indicated in this regard.

The policies are strongest and clearest in identifying jobs - and 'high quality' jobs - as a focus for policy development. The focus on jobs is also clearly linked to the fostering of new knowledge intensive industries. The fostering of these industries also emerges as a policy focus in its own right, because of a perceived importance of these new industries such as ICT and bio-business. The quality of 
these expected bio-jobs is, however, yet to be established. Nevertheless, the policies represent a targeted approach to job development.

The Innovation Policy reveals a very real attempt to grapple with the less tangible, more diffuse, though extremely central aspect of the knowledge economy, the innovation process. Defining innovation and the engineering of a culture that fosters innovation is an extremely difficult task. This policy represents a courageous first step towards making tangible advances in this area. However, making the right choices in education and infrastructure development are only part of the answer, as innovation needs to penetrate deeply into the region's business structure.

The ability of policy initiatives to penetrate the firm level is also a constant problem for economic policy makers. In Queensland firms have been primarily encouraged to participate in new industries through climate setting such as the development of infrastructure and the provision of a skilled workforce and funding $\mathrm{R} \& \mathrm{D}$. However there has also been an attempt to forge linkages between firms. As a result of our policy analysis we suggest that the Queensland policy 'vision' could be represented in the following way: The commercialisation of bio-discovery through: (1) association with a University; and (2) linkages with otherfirms; in (3) an incubator precinct; (4) driven by abilities in innovation and (5) staffed by a highly skilled workforce; (6) located within a state regulatory environment which facilitates such development; and (7) also recognises spill offs to the broader community; through (8) creating downstream employment benefit; while at all times (9) adding to the identity of the region; and (10) creating a vital magnet for resources and investment.

The reality of capturing and developing firms capable of delivering this vision should be the subject of further monitoring and research.

In addition, the policy frameworks have included a re-imaging of the external and internal identity of the state, from 'sunshine' to 'smart'. This is an important acknowledgement of the power and relevance of image to act as a mediator of the exchange process with key stakeholders in the economic development process, including the people of the state itself. The success of this re-imaging, particularly with Queensland people, needs monitoring and adjustment.

Finally, there has been a consistent focus on community and community development in the Smart State initiatives. This is in keeping with the foundations of the analysis of post-industrial society as advanced by Bell (1974), as well as being consistent with approaches advanced by the OECD. It is, perhaps, out of step with the current Federal economic development framework, though as Marsh (2001) has argued, the economic and social areas of policy have traditionally been cooperatively advanced in Australian society. It can be argued, however, that there has been some diffusion of the 'Smart State' focus resulting from the application of 'smartness' to an extremely wide range of community initiatives.

In conclusion, it is argued that there are in place in Queensland most of the macro policy elements necessary to foster the emergence of, and engagement with, the broad global knowledge economy/ society - a 'high skills' focus, the fostering of knowledge intensive industry development, a wide focus on innovation, a reimaging and identity development and an inclusion of community issues, rather 
than a narrow focus on economics alone. However, these policies are emergent, and are still reflective of a work in progress. This may be a result of the emergent nature of this field of economic policy development where knowledge economy frameworks themselves are still quite new. We believe the framework developed here may assist in such policy development and evaluation.

It is argued that it is necessary to develop a more focused set of polices around the broad policy direction now in place. These policies should refine some of the existing directions, particularly in the area of skills and education, but also more urgently seek to integrate many of the initiatives already in place and refine and better communicate the overall approach. As noted above, aspects of self-identity or 'living the brand' need to incorporate both existing and emerging core competencies.

Given the emergent nature of knowledge economy policies, it is argued that they should be accompanied by continuous review, particularly of their benefits to the broader community, a broad bi-partisan agreement concerning the direction for economic development in Queensland, a long-term policy horizon, and some tolerance of experimentation and failure. It has been beyond the scope of this paper to undertake a detailed analysis of the effectiveness of the policy directions for the knowledge economy emerging in Queensland. Such an evaluation would obviously be timely to incorporate with the preceding recommendations concerning a generally tighter, more focused policy regime. Queensland is engaged in a new and challenging era of economic development. Collaborative partnerships between business, community, government and academia in the area of economic, social and business policy development offer promise of the development of an informed and effective knowledge economy/society in Queensland.

\section{Note}

${ }^{1}$ Both authors contributed equally to this paper.

\section{References}

Anholt, S. 2002, 'Foreword' Journal of Brand Management, 94/5: 229-239.

Austrade Australian Trade Commission/ LEK Partnership 1994, Intelligent exports '...and the silent revolution in services,' Australian Trade Commission, Sydney.

Baker, J., Bullock, G., Hefferan, M. and Kuchler, D. 2001, Development of Technology Incubators, Parks and Precincts in Queensland - A Review and Start-Up Guide for Proponents, Department of State Development. Brisbane: Queensland Government.

Beattie, P. 1998, 'Beattie government sets priorities for 1999' Ministerial Media Statements. Available at: <statements.cabinet.qld.gov.au/cgi-bin/display-statement> Visited 20 December, 2002.

Beattie, P. 1999, 'Premier leads high-powered team on high-tech mission' Ministerial Media Statements. Available at: <statements.cabinet.qld.gov.au/cgi-bin/display-statement> Visited 20 December, 2002.

Beattie, P. 2001, 'Queenslanders offered a "smart" choice of number plates'. Available at: <statements.cabinet.qld.gov.au/cgi-bin/display-statements> Visited 20 December 2002.

Bell, D. 1974, The coming of post-industrial society, Heinemann, London. 
Bell, S. 1993 Australian manufacturing and the state, Cambridge University Press, Oakleigh.

Bell, S. 1997 Ungoverning the economy, Oxford University Press, Melbourne.

Boisot, M. H. 1998, Knowledge assets: Securing competitive advantage in the information economy, Oxford University Press, Oxford,

Cairney, T. 2000, The knowledge based economy: A review of the literature - Working paper, NSW Board of Vocational Education and Training, Sydney.

Capling, A. and Galligan, B. 1992, Beyond the protective state, Cambridge University Press, Melbourne.

Castells, M. 1989, The informational city, Blackwell, Oxford.

Clarke, T. 2001, The knowledge economy: Part one- Knowledge management,' Education + Training, 434/5: $189-196$.

Cohen, S. and Zysman, J. 1987, Manufacturing matters - The myth of the post industrial economy, Basic Books, New York.

Crouch, C. D., Finegold, D. and Sako, M. 1999, Are skills the answer? Oxford University Press, Oxford.

Darling, J. R. and Wood, V. R. 1990, 'A longitudinal study comparing perceptions of U.S. and Japanese consumer products in a third/neutral country: Finland 1975 to 1985,' Journal of International Business Studies, 213: 427-451.

Dow, G. and Parker, R. 2001 'Preface' Business, work, and community - Into the new millennium, Dow, G. and Parker, R. (eds) Oxford University Press, Melbourne.

Enright, M. J. and Roberts, B. H. 2001, 'Regional clustering in Australia,' Australian Journal of Management, 26 Special Issue: 65-86.

Finegold, D. and Soskice, D. 1988, 'The failure of training in Britain - Analysis and prescription,' Oxford Review of Economic Policy, 43: 21-51.

Gilmore, F. 2002, 'A country - Can it be repositioned? Spain - The success story of country branding', Journal of Brand Management, 94/5: 281-285.

Groenewgen, P. 1994, 'The political economy of federalism since 1970,' In State, economy and public policy in Australia, Bell, S. and Head, B. eds. Oxford University Press, Melbourne.

Grossman, G. M. and Helpman, E. 1995, Innovation and growth, MIT Press, Cambridge, Mass.

Hart, N. and Richardson, D. 1993, 'Industry policy under Labour', In The Australian economy under Labour, Mahoney, G. (ed.) Allen \& Unwin, St Leonards.

Higgins, W. and Ewer, P. 1987, 'Manufacturing decline and the politics of industry policy,' In Union strategy and industrial change, New South Wales University Press, Kensington.

Ind, N. 2001, Living the brand, Kogan Page, London.

Industry Commission. 1995, Tourism accommodation and training - Overview. Draft Report 15 November, 1995, Industry Commission, Canberra.

Jaffe, E. D. and Nebenzahl, I. D. 2001 National image and competitive advantage, Copenhagen Business School Press, Copenhagen, Denmark.

Jones, B. 1993 Sleepers wake! Technology and the future of work, Oxford University Press, Melbourne.

Kim, W. C. and Mauborgne, R. 1999, 'Strategy, value innovation and the knowledge economy,' Sloan Management Review, 403: 41-54.

Kotler, P. and Gertner, D. 2002, 'Country as brand, product and beyond: A place marketing and brand management Perspective,' Journal of Brand Management, 9(4/5): 249-261.

Kotler, P., Haider, D. H. and Rein, I. 1993, Marketing places: Attracting investment, industry and tourism to cities, states and nations, The Free Press, New York.

Kotler, P., Jatusripitak, S. and Maesincee, S. 1997, The marketing of nations: A strategic approach to building national wealth, The Free Press, New York.

Marceau, J. and Manley, K. 2001, 'Australia's System of Innovation,' Business, work, and community - Into the new millennium, Dow, G. and Parker, R. (eds), Oxford University Press, Melbourne.

Marsh, I. 2001, 'Economic strategies for a prosperous and fair society,' Australian Journal of Management, 26 (Special Issue): 1-10. 
McGaughey, S. L. 2002, 'Strategic interventions in intellectual asset flows,' Academy of Management Review, 27(2): 248-274.

Morgan, N. Pritchard, A. and Piggott, R. 2002, 'New Zealand, 100\% pure: The creation of a powerful niche destination brand,' Journal of Brand Management, 9(4/5): 335-354.

Nagashima, A. 1970, 'A comparison of U.S. and Japanese attitudes toward foreign products,' Journal of Marketing, 34 (January): 68-74.

Nagashima, A. 1977, 'A comparative "made in" product image survey among Japanese businessmen,' Journal of Marketing, 41(July): 95-100.

Neef, D. (ed.) 1998, The knowledge economy, Butterworth-Heinemann, Boston.

OECD 1996 The knowledge based economy, OECD, Paris.

Papadopoulos, N. and Heslop, L. (eds) 1993, Product and country images: Research and strategy, The Haworth Press, New York.

Pappas, Carter, Evans and Koop/Telesis Study. 1990, The global challenge - Australian manufacturing in the 1990s, Australian Manufacturing Council, Melbourne.

Parker, R. 2001, 'Australia's social system of production,' In Business, work, and community - Into the new millennium, Dow, G. and Parker, R. (eds) Oxford University Press, Melbourne.

Peterson, R. A. and Jolibert, A. J. P. 1995, 'A meta-analysis of country-of-origin Effects', Journal of International Business Studies, 26(4): 883-900.

Porter, M. E. 1990, The competitive advantage of nations, The Free Press, New York.

Porter, M. E. and Stern, S. 2002, 'Innovation: Location matters,' In Roberts E.B. (ed.) Innovation: Driving product, process and market change, Jossey-Bass, San Francisco, CA: 239-260.

Queensland Government. 2000. Putting families first, Queensland Government, Brisbane.

Queensland Government. 2002, Queensland bio-discovery policy A discussion Paper, Queensland Government, Brisbane.

Queensland Government 2002a Queensland R\&D strategy issues paper, Queensland Government, Brisbane.

Queensland Government Department of Innovation and Information Economy, 2001, Innovation directions for Queensland 2001 - An innovation framework supporting the smart state, Queensland Government, Brisbane.

Queensland Innovation Council, 2001 Innovation Directions for Queensland 2001 - An innovation framework supporting the smart state, Queensland Government, Brisbane.

Queensland Innovation Council, 2001a, Development of technology incubators, parks and precincts in Queensland - A review and start-up guide for proponents, Queensland Government, Brisbane.

Queensland Innovation Council<www.diiesrq.qld.gov.au/innovation/council > Visited 12 November, 2002.

Queensland Treasury 2000 Jobs for the future, Queensland Government, Brisbane.

Queensland Treasury 2002 Queensland - Growing the Smart State. Queensland Government, Brisbane.

Roberts E. B. (ed.) 2002, Innovation: Driving product, process and market change, Jossey-Bass, San Francisco, CA.

Romer, P. M. 1994, 'The origins of endogenous growth', Journal of Economic Perspectives, 8 (Winter): 3-22.

Roth, A.V., Marucheck, A.S., Kemp, A. and Trimble, D. 1994, 'Knowledge factory for accelerated learning processes', Planning Review, 22 (3): 23-33.

Sassen, S. 1991, The global city. Princeton University Press, Princeton.

Satoh N, Nakayama, T. and Wakuta, Y. 2002, 'Bio business strategy of Japanese traditional industry', Management in the global context: Prospects for the $21^{\text {st }}$ Century - Proceedings ANZAM/ IFSAM VI World Congress - Gold Coast $10^{\text {th }}-13^{\text {th }}$ July 2002.

Schooler, R. D. 1965, 'Product bias in the central American common market,' Journal of Marketing Research, 2(November): 394-397. 


\section{GILLIAN SULLIVAN MORT AND AMANDA ROAN}

Sheehan, P. and Tikhomirova, G. 1998, 'The rise of the global knowledge economy' in Sheehan, P. and Tegart, G. (eds) Working for the future: Technology and employment in the global knowledge economy, Victoria University Press, Melbourne.

Stewart, R. G. 1990, 'Industry policy,' In Hawke and Australian public policy -Consensus and restructuring, Jennett, C. and Stewart, R.G. (eds) MacMillan, South Melbourne.

Sullivan Mort, G. M. 1999, Multifaceted country image impact on behaviour intentions for goods and services: A study in the APEC region, Unpublished Doctoral Thesis, University of Queensland.

Wiltshire, K. 2002, Personal communication. 